\title{
Shi Tiesheng \\ LIKE A BANJO STRING / TRANSLATION FROM THE CHINESE, INTRODUCTORY ARTICLE AND COMMENTARIES BY N. CHERNYSH
}

\author{
N. Chernysh \\ PhD (Philology), Associate Professor \\ Oles Honchar Dnipro National University \\ 72, Gagarin avenue, Dnipro, 49010, Ukraine \\ nata.kitashi@gmail.com \\ ORCID ID: 0000-0002-2384-1481
}

The reader is invited to get acquainted with the works of the famous Chinese writer Shi Tiesheng, a prominent author of novels, short stories and essays of the $20^{\text {th }}$ century. Many of his works are included in textbooks of Chinese schools. Academic interest in Shi Tiesheng's work is increasing every year; in particular, many studies are devoted to his story Like a Banjo String ("命 若 琴弦”). The story Like a Banjo String has all features of a parable. It is both an instructive and allegorical plot, built on a hidden comparison, and also symbolism, imagery, and vivid allegory. The story is characterized by the principle of the parable: it seems to break away from the given space and, moving along the curve, turns back, gives a philosophical and ethical understanding of the subject, 'the timeless' contains a description of modernity, concrete action communicates the eternal.

According to the author of the translation, it is the philosophy of A. Camus that helps to better understand the story-parable of Shi Tiesheng. We can assume that Shi Tiesheng himself was familiar with the philosophy of A. Camus, whose works began to be published in Chinese in 1958. In the image of the protagonist of his parable, Shi Tiesheng asks the same questions as Camus in his famous essay on the absurd, The Myth of Sisyphus: what motivates a person to act, what is a sense of absurdity, a sense of hope and hopelessness, a thirst for clarity (the absolute), reconciliation with fate, creativity, etc. Reflecting on the absurdity of human life, Shi Tiesheng seeks a solid basis for it. In the story Like a Banjo String the winner in the confrontation with fate is not the stoic acceptance of one's fate, supported by an understanding of its absurdity and freedom of action, but the ability to dissolve oneself in another, to see another, to shift one's attention to another, and this ability of mind or state of mind, or the nature of the character in the Chinese tradition is called humanity, philanthropy and even 'conscience'. These words are united by the hieroglyph 仁 ren.

The Ukrainian translation of the story Like a Banjo String is done for the first time.

Keywords: Shi Tiesheng, Like a Banjo String, story, parable, allegory, metaphor, principle of the parable, absurd, A. Camus, The Myth of Sisyphus

\section{Ши Темен}

\section{ЖИТТЯ ЯК НАТЯГНУТА СТРУНА /}

ПЕРЕКЛАД З КИТАЙСЬКОЇ, ВСТУПНА СТАТТЯ TA КОМЕНТАРІ Н. О. ЧЕРНИШ

Сучасна китайська література багата іменами письменників, інтерес до яких виходить за межі самого Китаю. Це і відкриті світу Нобелівською премією Мо Янь (莫 言) та Гао Сінцзянь (高行健), і відомі в перекладах європейськими мовами А Чен (阿城), Чжан Сяньлян (张贤亮), Юй Хуа (余华), Ван Мен (王蒙), Фен Цзіцай (冯䩀 才) Цзя Пінва (贾平凹) та багато інших. Вони належать літературі нового періоду

(C) 2021 N. Chernysh; Published by the A. Yu. Krymskyi Institute of Oriental Studies, NAS of Ukraine on behalf of The World of the Orient. This is an Open Access article distributed under the terms of the Creative Commons Attribution License (https://creativecommons.org/licenses/by-nc/4.0/). 
(新时期文学), твори якої написані переважно після Культурної революції (文化大革 命 1966-1976).

Ши Тєшен (史铁生) входить до групи письменників, які в 1960-х роках, під час Культурної революції, у ході політичного руху “У гори, у села” (上山下乡) пройшли через “трудове перевиховання" в найбідніших районах Китаю. Їх назвуть “освічена молодь, яка спрямована в села” (下乡知青). Для Ши Тєшена це було місто Яньань (延安) у провінції Шеньсі. Але повернувся він у рідний Пекін інвалідом, тому література стала для нього єдиною можливістю існування, якщо не виживання. Боротьба з хворобою, яка залишала дедалі менше часу для письма, стала щоденною даністю його життя. Він з гіркотою каже: "Мої хвороби - це моя робота, а пишу я у вільний від роботи час" (我的职业是生病, 业余写点东西) [史铁生]. У цьому одна 3 причин його виразної, сильної і напруженої мови. Тривала хвороба змусила його уникати галасливої метушні світу, він занурився в глибокі роздуми про ключові питання людства, про смерть і долю, про дух і душу, про хворобу і віру, про страждання і любов. “Жити - не для того, щоб писати, а писати - для того, щоб жити” (活着不 是为了写作, 而写作是为了活着), - скаже він про себе [史铁生 2016]. Ши Тєшен пише не про соціальне життя людини певного часу, а зосереджується на описі й вивченні індивідуального духовного шляху, прихованого від зовнішнього погляду. Звідси і його увага до життя людини з інвалідністю, фізичне життя якої обмежене, тому завдання виживання стоїть перед нею понад усе. Часто в літературі убогі каліки виставляються як смішні, страшні, безпорадні, жалюгідні люди. Вони гідні співчуття і потребують допомоги. У Ши Тєшена погляд із середини. Його герой - сильна духом людина, яка після початкового жаху від усвідомлення фізичної неповноцінності переходить на рівень прийняття долі, до неї приходить розуміння того, що фізична обмеженість не перекриває життєвий шлях, а робить його інакшим. Життя набуває нового сенсу, який потрібно ще тільки осягнути і знайти.

Академічний інтерес до творчості Ши Тєшена з кожним роком зростає. У Китаї на найбільшій освітній платформі для журналів “浅论天下” налічуються сотні магістерських, докторських дисертацій і наукових статей, присвячених різним питанням творчості письменника, багато з яких присвячені саме його оповіданню “Життя як натягнута струна” (“命若琴弦”). Автори статей обговорюють питання розуміння твору, особливості викладання його в школі, порівнюють 3 відомою екранізацією фільму режисера Чень Кайге (陈凯歌) “Йди і співай” (“边走边唱”), 3 ідеями європейської літератури (екзистенціалізм, абсурд у міфі про Сізіфа). У творі Ши Тєшена знаходять основні мотиви китайської класичної філософії - даосизму та буддизму.

Мова Ши Тєшена проста та напружена. Опис природи лаконічний. Вся увага письменника зосереджується на звуках, які заповнюють світ сліпої людини, тому в оповіданні так багато вигуків і звуконаслідувальних слів, що виражають емоційну реакцію на те, що відбувається навколо. Складним для перекладу виявилося місце розповіді, де йде гра слів - омонімів - youlang 游廊 i youlang 油 狼. Коли юнак, персонаж розповіді, чує незнайоме слово юлан (游廊 youlang), він уявляє те, що знає: юлан - це масляний вовк (油狼 youlang), - проте абсурдність цього словосполучення не залишає його в спокої, і він запитує всіх, що ж це таке. Ши Тєшен підказує читачеві, що мова йде про прогулянкову галерею - традиційну китайську будову, яка зазвичай розташована в парках. Це візуальне мистецтво, яке недоступне сліпій людині. Однак бажання сліпого бачити і знати те, що бачать і знають усі зрячі, є основною спонукальною причиною дій героя розповіді. Сліпі не можуть зрозуміти, про що йде мова в радіоприймачі, незнайоме слово вони чують як безглузде словосполучення - масляний вовк 油狼 youlang, омонімічне йому словосполучення - петляста галерея 游廊 youlang - залишається за межами їхнього розуміння до кінця твору. 
Оповідання “Життя як натягнута струна” має всі ознаки притчі. Це й повчальноалегоричний сюжет, побудований на прихованому порівнянні; це й символічність, образність, яскрава алегоричність. Оповідання має підтексти, алюзії, розвинену асоціативність, моралізаторство і навіть дидактизм. Ольга Токарчук у нобелівській лекції говорить про те, що алегорія пішла з літератури і це “свідчить про нашу нинішню безпорадність... Герой алегорії - людина, яка живе за певних історичних і географічних умов, і водночас вона виходить за межі цих конкретних обставин, перетворюється на Універсальну Людину Світу" [Токарчук 2019]. Здається, треба уважніше придивитися до китайської літератури, тут можна несподівано знайти багато значного в розумінні Універсальної Людини Світу.

У новітній європейській літературі до притчі відносять принцип параболи: оповідь немовби відривається від зазначеного часопростору i, рухаючись по кривій, повертається назад, дає філософсько-етичне осмислення предмета, у “надчасовому” міститься характеристика сучасності, конкретна дія повідомляє про вічне. «Притча - це розповідь не просто про якісь людські справи, а й про “небесну реальність”», - каже Крейг Бломберг [Бломберг 2005, 16]. Оповідання Ши Тєшена саме таким і є. Притча - це також розгорнуте порівняння. Оповідання “Життя як натягнута струна” (“命若琴弦” mìng ruò qínxián) самою назвою підтверджує це правило притчі. Подивимося на перше слово 命 (ming), словники дають такі значення: наказ, мандат, воля неба, доля, рок, і лише п'яте значення - роки життя і саме життя. Тобто для слова 命 (ming) основне лексичне значення - “доля” і потім уже - “життя”. У сучасному вживанні слово 命 (ming) зазвичай складається з двох ієрогліфів 生命 (shēngmìng - життя і доля, життєва доля), 人命 (rénmìng - людське життя), 性命 (xìngmìng - життя, характер і доля), 寿命 (shòumìng - тривалість життя, доля), тобто 命 (ming) у звичайному вживанні - “життя”, у філософському - “доля”. Якщо Ши Тєшен і говорить про життя, то про таке, яке стає долею. Доля як натягнута струна. Перефразовуючи слова А. Камю, скажемо: натягувати струни - це надавати форми своїй долі (А. Камю: “Творити - це надавати форми своїй долі”).

Цікаво, що краще зрозуміти розповідь-притчу Ши Тєшена допомагає саме А. Камю. Можна припустити, що Ши Тєшен був знайомий з філософією А. Камю, твори якого вже з 1958 року почали публікуватися китайською мовою. Ши Тєшен в образі головного героя своєї притчі ставить ті ж питання, що й Камю в знаменитому есе про абсурд: що спонукає людину до дії, що таке почуття абсурду, почуття надії та безнадії, що таке жага ясності (абсолюту), примирення з долею, творчість та інші.

Розмірковуючи про абсурдність людського життя, Ши Тєшен продовжує шукати надійну основу для нього. Звернімо увагу на мотив людяності, який мимохідь показаний у міфі про Сізіфа Камю, але органічно вплетений у розповідь Ши Тєшена і далі розвинений режисером Чень Кайге. Герой Камю - Сізіф - набуває ясновидіння, яке мало бути його мукою, але стає його перемогою. Він знає про нескінченність своїх мук та водночас чує в несподівано безмовному всесвіті шепіт тисяч тоненьких чудових голосів, які линуть із землі. Камю скаже: “Переконаний у першопричині всього людського, що є людським, як той сліпий, що прагне прозріти, знаючи, що ночі не буде кінця, Сізіф у вічному русі” [Камю 2015, 94-95]. Камю не розвиває тему людського в долі Сізіфа. Він самотній, і схоже, що його боротьба 3 богами триває, щоб довести їм свою незалежність від них. Йому цікаво рівнятися 3 богами. Якщо він і приймає абсурдність творчості, то тільки як прикрасу всеосяжної порожнечі, як виклик богам: “Однієї боротьби за вершину досить, щоб заповнити серце людини. Сізіфа слід уявляти собі щасливим” [Камю 2015, 95]. Його щастя - боротьба з богами. Ця висока боротьба абсурдна і відбувається на самоті.

Китайській літературно-філософській традиції є чужою тема богоборства. Але тема протистояння долі або розпізнання іiї законів вже $\epsilon$ в “Книзі змін”. Цікаво, що

The World of the Orient, 2021, № 1 
в оповіданні Ши Тєшена в протистоянні долі перемагає не стоїчне прийняття своєї долі, що підкріплюється розумінням іiі абсурду і свободи своїх дій, а розчинення себе в іншому, бачення іншого, перенесення своєї уваги на іншого, і ця здатність розуму, чи стан духу, чи природа характеру, називаються в китайській традиції “людяність”, “людинолюбність” (Л. С. Переломов), “гуманність” (О. С. Мартинов) і навіть “совість” (Л. І. Головачова). Ці слова об’єднує ієрогліф жень 仁 (ren) - поняття старокитайської філософії, яке є центральним у вченні Конфуція (виправлення імен, справедливість та ритуал неможливі без жень - без людяності), але припустімо, що це поняття і $є$ центральною темою китайської літератури взагалі.

Ієрогліф жень 仁 має дві графеми, дві частини: “людина + два”. Китайські вчені здебільшого трактують поєднання цих графем так: дві людини, які прямують одна за одною (“从人, 从二”), прямувати за кимось, як прямувати за рідною, кровною людиною: “仁, 亲也”. Прямувати за кимось, переймати знання, досвід, а може, й долю - ця тема наповнює цей твір таємним змістом, який розгадати мусить сам читач. Ши Тєшен залишає читача наодинці з цим питанням.

У 1991 році був опублікований збірник перекладів англійською мовою оповідань Ши Тєшена під назвою "Strings of Life". У 2007 році оповідання “Життя як натягнута струна" вийшло російською мовою у збірнику "Современная китайская проза. Жизнь как натянутая струна". Переклад українською здійснено за виданням: Ши Тєшен. Життя як натягнута струна. Збірка творів. Видавництво “Чжунго хуанвень", 2008, 193 c. (史铁生著。“命若琴弦”散文集。中国盲文出版社，年，页).

У сизих заростях гірських схилів йшли двоє сліпців. Один - старий, другий - молодий, один - попереду, другий - позаду. Два почорнілих солом'яних капелюхи поспішно просувалися вперед, немов неспокійний річковий потік. Неважливо, звідки йшли, і неважливо, куди йшли, кожен мав музичний інструмент - саньсянь ${ }^{1}$. Вони шошуди ${ }^{2}$, які заробляють на життя розповідями, грою на саньсяні та піснями.

Серед гір на сотні й тисячі лі навкруги гірські шпилі накладаються один на одного, уздовж і впоперек лежать западини, рідко де є людське житло. Потрібно йти цілий день, щоб побачити відкриту місцевість, де є кілька сіл. Час від часу з глухих заростей злітають фазани, вистрибують дикі зайці, лиси або інші звірки, у долинах незмінно парять яструби.

У пустельних горах немає ні одної тіні, нещадно палить сонце.

- Візьми саньсянь у руки, - крикнув старий, і в горах відгукнулася луна.

- У руках, - відповів юнак.

- Потурбуйся про те, щоб піт не промочив саньсянь, намокне - будеш увечері грати на своїх ребрах.

- Взяв у руки.

I старий, і юнак обидва були по пояс оголені, кожен тягнув у руках дерев'яний ціпок, а намотана на поясі сорочка із грубої тканини вже майже вся вимокла. Це якраз найгарячіша пора для мандрівних оповідачів. Довгими днями, повечерявши, сільські люди не сидять удома, та й вечеряють не вдома, а беруть у руки їжу і виходять до дороги або на робочий майданчик. Старий хоче розповісти якомога більше історій, за весь спекотний сезон треба встигнути разом з юнаком обійти всі села, відіграти всі вечори. 3 кожним днем старий дедалі більше нервується й хвилюється, думає про себе: день, коли порветься тисячна струна, настане вже цього літа і може бути вже в цій долині Диких Овець.

Сонце, що безжально палило вдень, до цього часу трохи заспокоїлося, світло стало глибшим. Там і тут сюрчали цикади, які теж значно притихли.

- Синку, чи не можна швидше? - не повертаючи голови і не уповільнюючи кроків, закричав попереду старий. 
Юнак поспішно підбіг на кілька кроків, зашуміла сумка, що висіла на довгому ремені, однак до старого, як і раніше, залишалося ще кілька сажнів.

- Вже дикі голуби полетіли в гнізда.

- Що? - юнак знову підбіг на кілька кроків.

- Кажу, що вже дикі голуби повернулися в гнізда, а ти все не поспішаєш.

- Еге ж!

- Ти знову вовтузишся з моїм приймачем.

- Хе! То біси граються.

- Через тебе навушники будуть зламані.

- То біси граються!

Старий тишком усміхнувся: скільки днів живе цей хлопчисько?

- Я чую, як мурахи б'ються, - сказав старий.

Юнак не сперечався. Тихцем засунув у сумку навушники й з нудним виразом пішов за вчителем по нескінченній нудній дорозі.

Деякий час ішли, коли юнак почув, як борсук гризе посіви. Він тут же загавкав, як собака, і борсук кинувся тікати. Йому стало веселіше, і він стиха наспівав одну пісеньку: о брати, о сестри. Вчитель не дозволяє йому мати собаку, боїться, що сільські собаки зачіпатимуть його, боїться й того, що він ображатиме сільських собак і тоді вони втратять свою справу. Пройшли ще трохи, і юнак почув, як удалечині повзе змія. Зігнувшись, схопив камінь і кинув у неї. Зашуміло листя гаоляну. Старому стало трохи шкода юнака, він зупинився в очікуванні.

- Не борсук, так змія, - поспішно сказав юнак, хвилюючись, що вчитель буде лаяти його.

- Скоро хлібні посіви, вже недалеко, - старий передав флягу з водою учневі. У нашій справі все життя проводиш на ногах, - знову сказав старий, - втомився, ні?

Юнак не відповів, бо знає, що вчитель найбільше не любить, коли він говорить про втому.

- Тільки прикро за мого вчителя. Так, дуже прикро, за все життя обійшов увесь світ і помер, так і не зігравши на тисячній струні саньсяня.

Юнак почув, що в старого зараз гарний настрій, та й запитав:

- Що таке зелена лава?

- Що? А, напевно, це лавка.

- А масляний вовк? - У приймачі казали про петлясту галерею, яка співзвучна масляному вовку.

- Вовк? Який вовк?

- Масляний вовк.

- Не знаю.

- У приймачі казали.

- Любиш же ти безглуздо слухати порожні дурниці. Що в тому, що ти їх слухаєш? У Піднебесній багато гарного, але який це має до нас стосунок?

- Я не розчув, що має до нас стосунок? - Юнак виділив слово “має”.

- Саньсянь! Твій батько відправив тебе до мене для того, щоб ти грав на саньсяні і зміг стати мандрівним музикантом.

Юнак навмисно голосно надпив води.

Тепер попереду йшов юнак.

Гірські тіні покрили ущелини. Місцевий рельєф поступово вирівнювався і розширявся. Наближаючись до села, старий гукнув юнака. Біля тінистого підніжжя гори він знайшов невелике джерело. 3 кам'яної ущелини назовні просочувався тонкий струмок води. Вона збиралася в круглій западині, навколо пишно росла трава, на десятки метрів текла вода, яку вбирала в себе спрагла земля.

- Підійди помийся, вимий свій смердючий піт. 
Юнак відсунув траву біля води і сів навпочіпки, все ще думаючи про того “масляного вовка".

- Все тіло вимий, у такому вигляді ти схожий на безвусого жебрака.

- Тоді ви хіба не перестаркуватий жебрак? - юнак, сміючись, опустив руку у воду.

Старий теж сміявся, двома руками зачерпнув води і хлюпнув собі в обличчя.

- Але ми не жебраки, у нас є ремесло.

- Схоже, тут ми вже були, - юнак уважно вслуховувався в навколишні звуки.

- Але ж твої думки вічно десь не в навчанні. Ти такий неотесаний, ніколи не слухаєш те, що каже старий.

- Ми напевно тут були.

- Не перебивай! На саньсяні граєш погано. Наше життя тільки в цих декількох струнах. Мій учитель колись саме так мені казав.

Джерельна вода була чистою й прохолодною. Юнак знову замугикав щось про братів і сестер. Старий розсердився.

- Ти почув, що я сказав?

- Наше життя тільки в цих декількох струнах, вашим учителем, моїм учителем сказано. Я вже вісімсот разів чув. Ще ваш учитель залишив один рецепт, за яким потрібно обірвати тисячу струн і тільки тоді можна дістати якісь ліки. Вживши їх, ви відразу побачите світ. Я чув ці ваші слова тисячу разів.

- Не віриш?

Юнак ухилився від відповіді і лише сказав:

- Чому, тільки обірвавши тисячу струн, можна дістати якісь ліки?

- Це умова рецепта, розумнику. Ліки мусять мати свою умову.

- Чи важко порвати тисячу струн інструмента? - юнак нестримано захихикав.

- Що смієшся? Ти думаєш - багато розумієш? Потрібно по-справжньому, струна за струною, всі обірвати, тільки тоді вийде.

Почувши, що вчитель знову злиться, юнак не наважився щось казати. I так щоразу, у цій справі вчитель не може дозволити собі і грама сумніву.

Старий теж більше не проронив жодного звуку, видавався трохи схвильованим, поклав обидві руки собі на коліна, два нерухомих ока уперлися в сизе небо, наче згадували одну за одною всі обірвані струни. "Скільки ж років очікування? - думав старий. - П’ятдесят років очікування!” За п'ятдесят років скільки гір обійшов, скільки верст пройшов, скільки палючого сонця і холоду витерпів, а скільки образ! Вечір за вечором, граючи, завжди пам'ятав одне: потрібно по-справжньому, всіма силами душі обірвати струну, одну за одною, і тільки тоді вийде. Зараз ось-ось це трапиться, навіть і літо ще не мине. Старий знає, що не хворіє смертельною хворобою, це літо зовсім не складно прожити. "Я, на відміну від свого вчителя, більш удачливий, - сказав він, - мій учитель помер, так і не глянувши на світ жодного разу”.

- О! Я знаю, що це за місце! - раптом скрикнув юнак.

Старий тільки зараз поворухнувся, взяв свій інструмент і потряс його. Складений аркуш паперу натрапив на зміїну шкіру інструмента і видав тонкий шелесткий звук. Той рецепт був саме в корпусі інструмента.

- Вчителю, це хіба не гірський хребет Диких Овець? - запитав юнак.

Старий не звернув на нього уваги, але відчув, що цей хлопчисько знову став неспокійним.

- Попереду саме долина Диких Овець, чи не так, учителю?

- Підійди потри мені спину, - сказав старий, вигнувши спину, немов лук.

- Чи це не долина Диких Овець, учителю?

- Так! Навіщо? Що ти розійшовся, наче кішка.

У юнака серце схвильовано застукотіло, він старанно тер спину вчителю.

Старому здалося, що він уже занадто тре. 
- Що з того, що це долина Диких Овець? Не треба, немов віслюк, винюхувати.

Юнак розгубився, нічого не сказав, не хотів показувати власне хвилювання.

- Про що знову думаєш? Не треба вважати, що я не знаю твоїх думок.

- А що я?

- Що ти? Минулого разу ти тут мало божеволів? Що хорошого в тому дівчиськові?

Старий подумав, що, можливо, непотрібно більше брати його в долину Диких

Овець. Однак долина Диких Овець - це велике село, щоразу тут справи йдуть добре, можна виступати майже місяць. Старий був роздратований тим, що не може відразу обірвати останні кілька струн.

Юнак щось бурмотів, але душа його літала, він думав про ту дівчину з пронизливим голосом, яка живе в долині Диких Овець.

- Послухай, що я кажу. Тобі не зашкодить, - сказав старий. - Це справа ненадійна.

- Яка справа?

- Не базікай. Ти знаєш, про що я.

- Я тільки не розчув, яка справа ненадійна.

Юнак знову тишком усміхнувся. Старий не звернув на нього уваги, нерухомі очі знову звернулися до неба. Там сонце якраз перетворювалося на пляму крові. Дві спини, немов гори, були однакового жовто-коричневого кольору. Одна - вже постаріла. Худі кістки - все одно що голе каміння біля підніжжя гір. Інша - поки що молода. Старому - сімдесят, юнаку тільки сімнадцять.

Юнаку виповнилося чотирнадцять, коли батько віддав його старому, щоб він вчився майстерної гри для людей. У цьому житті добре мати якесь вміння - у майбутньому можна жити самостійно.

Вже понад п’ятдесят років старий був мандрівним музикантом. У глухих гірських місцинах люди знали його: 3 кожним днем волосся ставало сивішим, а спина - все одно що у верблюда. Цілі місяці і роки з саньсянем за спиною ходив по всьому світу. Прийде туди, де бажають розлучитися з грошима, розгорне інструмент і співає весь вечір, приносячи радість одиноким поселенням. На початку зазвичай співав такі слова: "З3 тих пір як Пань-гу³ розділив Небо і Землю, з часів правління трьох володарів і п'яти імператорів ${ }^{4}$ і до сьогодні правитель, який має шлях, наводить порядок у Піднебесній, правитель без шляху шкодить народу. Саньсянь легко грає, пісня неспішно оповідається. У мене більше ніж три тисячі пісень, не знаю, яка торкне серце”. I тоді слухачі починали шуміти, люди похилого віку хотіли чути про те, як Дун Юн ${ }^{5}$ продав тіло, щоб поховати батька, молоді хотіли почути про У Ерлана 6 , який уночі йшов по горі сколопендр. Жінки хотіли чути про Цінь Сянляняㄱ. Саме цей час приносив старому найбільше задоволення. Він забував про душевну самотність і про фізичну втому, чекав, коли шум натовпу дійде до найвищої точки, не поспішаючи випивав кілька ковтків води, одним рухом натягував струни і починав співати: “Сьогодні заспіваємо не про когось, а про принца Ло Че-

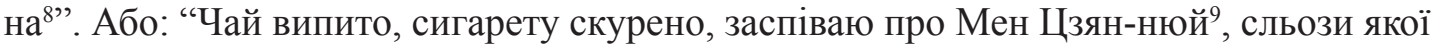
обрушили Велику стіну”. На всьому майданчику відразу ж запановувала тиша, і старий усім серцем заглиблювався в свої історії...

Старий знав їх безліч, ще й був приймач, який, казали, він купив за велику суму з рук чужинця, для того щоб учити нові слова, добирати нові пісні. Насправді, про що він співав, людям цих гір було не так важливо. Їх захоплювало його вміння грати на саньсяні, то неквапливо, легко і плавно, то хаотично і нестримно. Там було все: сонце й місяць у небі та живий дух на землі. Старий вмів узяти горлом будьякий чоловічий чи жіночий звук, зобразити подих вітру або шум дощу, крики звірів або співи птахів. Ніхто не знав, які образи народжувалися в нього в голові. Він уже народився сліпим і ніколи не бачив цей світ.

Можна вважати, що юнак бачив цей світ, хоча тільки у свої перші три роки, коли ще нічого не розумів. До гри на інструменті і до розповідей у нього зовсім не було

The World of the Orient, 2021, № 1 
інтересу. Коли батько привів його до старого, витратив усі слова, умовляв його і навіть вдавався до хитрощів. У результаті подіяли не слова, а той приймач захотів усю увагу юнака. Він узяв його в руки, захоплено слухав і не помітив, коли батько пішов.

Ця таємнича скринька назавжди привернула його увагу. Далекі землі і таємничі стародавні події несли його в нескінченні фантазії. Невиразно по пам'яті до трьох років він надавав кольори і форми багатьом речам, як-от, наприклад, море. Коли у скриньці казали про те, що блакитне небо схоже на море, він згадував небо, міг уявити і море; у скриньці казали про море як про безмежні води - він згадував воду в казані, тому уявляв собі небо повністю з розставлених казанів. Або, наприклад, у скриньці казали про гарну дівчину, яка схожа на розквітлу квітку. Він не повірив, що так насправді може бути: коли труну матері забрали в далекі гори, на дорозі якраз всюди розквітли польові квіти, він назавжди запам'ятав їх, але ніколи не хотів думати про них. Однак йому хотілося думати про дівчат. Чим далі, тим більше. Особливо про ту, з пронизливим голосом з долини Диких Овець, яка завжди викликала в ньому сильне сердечне хвилювання. Одного разу у скриньці прямо заспівали: “Очі дівчини такі схожі на сонце”, і тільки тоді він знайшов близький образ, згадавши обличчя матері, що йде до нього у вечірніх променях сонця. Справді, кожна людина на основі своїх знань може вгадувати безмежність непізнаного і на основі своїх почуттів може зробити начерк світу. Але світ у кожного - свій.

Було й інше, що юнак не міг собі уявити, наприклад “масляний вовк".

Цього вечора юнак і вчитель виступали в долині Диких Овець, і знову він почув, як та дівчина 3 пронизливим голосом десь недалеко від нього сміялася і жартувала. Їхня історія якраз дійшла до напруженого місця: “Ло Чен розвертає коня і знову вступає в бій, сміливий Су Лє ${ }^{10}$ знову збирає воїнів. Меч у Су Лє немов стрімкий водний потік, зброя в Ло Чена немов потужні хмари, здається, що дракони б'ються за перлину в морі, ніби десь у горах тигри змагаються. Сім днів і ночей б'ється Ло Чен, і ковток чаю ніколи випити...” Гра старого була подібна раптовому дощу і поривчастому вітру, слова і фрази лунали ритмічно і звучно. Але голова юнака була зайнята іншим, всі пісні давно вже перемішалися під рукою...

У двох верстах від долини Диких Овець у горах був храм. Учитель та учень тут і зупинилися. Складені з каменю стіни храму були частково зруйновані. Кілька палацових залів теж були готові впасти, тріщали по всіх швах. I тільки один центральний зал ще міг сховати від вітру і дощу, мабуть, тому, що тут все ще робили жертвопринесення духам. Три глиняні статуї давно вже скинули мирські барв і прикраси, повернули собі природний колір жовтої землі, повернули правду необробленого каменю, так що не розібрати було, буддійські вони чи даоські. Всередині і зовні, всюди на даху і на стінах пишно розрослися повзучі трави - хоч якась життєва енергія. Щоразу, діставшись долини Диких Овець, старий зупинявся тут. Не сплачуєш за житло - не створюєш зайві неприємності. Юнак прийшов сюди вдруге.

Коли стало зовсім пізно, всі розійшлися. Старий у головному залі складав речі, юнак у бічному залі під карнизом роздмухував вогонь у печі. Складену у минулому році піч трохи підремонтували, отже, вона годилася до використання. Юнак, стоячи на колінах, роздмухував вогонь. Хмиз був не сухий, хлопець поперхнувся, і на весь храм пролунав його кашель.

Старий у головному залі весь час бурчав на нього.

- Ось дивлюся, що ти вмієш робити?

- Хмиз відвологнув.

- Я не про це. Я кажу про твою гру. Що ти грав сьогодні ввечері?

Юнак не наважився продовжити цю тему. Вдихнув кілька ковтків повітря, 3 надутими щоками він знову став на коліна перед піччю і з силою видихнув. 
- Якщо не хочеш цим займатися, гаразд, поки не пізно, повідомлю твого батька, нехай тебе забирає. Не годиться завжди як кішка з собакою сперечатися. Хочеш сперечатися - повертайся додому.

Юнак 3 кашлем відскочив од пічки і швидко опинився в іншому кінці залу, важко перевів дух та вилаявся.

- Щось сказав?

- Лаю вогонь.

- Хто так роздмухує!

- А як роздмухувати?

- Як роздмухувати? Отакої.

Старий помовчав і знову сказав:

- Уяви, що цей вогонь і є обличчя того дівчиська!

Юнак не наважився підтримати розмову, навпочіпки дістався до печі, знову подув та подумав: а й правда, не знаю, яке ж обличчя в Лань Сюр (так звали ту дівчину з пронизливим голосом).

- Так ось, якщо говорити про обличчя того дівчиська, то бачу, не треба вчити тебе дути, - сказав старий.

Юнак розсміявся і ще більше закашлявся.

- Чого смієшся?

- А ви дули в обличчя дівчини?

Старий відразу ж замовк. Юнак сидів на землі та сміявся.

- Чорт забирай, - вилаявся старий, усміхнувся, після чого змінився в лиці і більше не промовив жодного слова.

У пічному отворі щось бухнуло: вогонь розгорявся. Юнак пішов за хмизом, думаючи весь час про Лань Сюр. Увечері, коли розходилися по домівках, Лань Сюр у натовпі була відтиснута до нього, вона прошепотіла: “Гей, минулого разу ти що обіцяв?” Він не наважився й слова сказати - поруч був учитель. Натовп тиснувся тудисюди, і знову Лань Сюр з'явилася біля нього. “Ага, хто минулого разу їв варені яйця, що, даремно?” - промовила голосніше. У цей час учитель був зайнятий розмовами з іншими, тому він квапливо сказав: “Тс-с, пам'ятаю”. Лань Сюр знову тихо прошепотіла: “Ти обіцяв мені дати послухати приймач, а досі не дав”. - “Тс-с, пам'ятаю”. Добре, що в цей момент було дуже шумно.

У головному залі довго не було руху. Потім стало чутно звуки саньсяня, старий знову заправив нову струну. Раніше він був би дуже задоволений, що в перший же вечір порвав струну. Однак зараз звуки були низькі і хаотичні.

Юнак поступово розчув неточні звуки інструмента й крикнув:

- Вода закипіла, вчителю!

Відповіді не було. Звуки з кожною хвилиною ставали дедалі напруженішими. Юнак вніс таз гарячої води і поставив перед учителем. Удавано усміхнувся й сказав:

- Ви хочете сьогодні ввечері порвати ще одну струну, чи як?

Старий не почув. Зараз він був весь у собі. Звуки саньсяня були нервові і неспокійні, немов довгий дощ та вітер, немов безкрайні степи, немов струмок, що нескінченно тече з ущелини, немов метушливі кроки, які не знають дороги додому. Юнакові стало трохи страшно: вчитель дуже давно не був таким. Як тільки стає таким, відразу хворіє, голова болить, серце і горло болять, все тіло болить, може кілька місяців не вставати з ліжка.

- Вчителю, помийте ноги.

Звуки не припинилися.

- Вчителю, вам пора ноги мити, - голос юнака затремтів.

Звуки не припинилися.

- Вчителю!

The World of the Orient, 2021, № 1 
Звуки саньсяня раптово стихли, старий глибоко зітхнув. Юнак з полегшенням перевів дух.

Старий мив ноги, юнак покірно сидів біля нього.

- Іди спати, - сказав старий, - сьогодні добряче втомився.

- А ви?

- Ти йди спати, мені треба гарненько помочити ноги. 3 віком у людини більше болячок, - відповів з удаваною легкістю старий.

- Я дочекаюся, будемо разом засинати.

Вночі тихо в горах. Трохи подув вітер, і вже шурхотять кучеряві трави на стінах. Десь далеко жалібно кричала сова. Чутно, як у долині Диких Овець несподівано загавкали собаки, і потім долинув дитячий плач. Зійшов місяць і через поламану віконну гратницю проник у зал та осяяв двох людей і три статуї святих.

- Навіщо мене чекати? Пізня година... Ти за мене не хвилюйся, я вже якось так, знову сказав старий, - чуєш чи ні?

Зрештою, юнак був молодий і швидко заснув. Старий підштовхнув його, щоб він зручніше ліг, той пробурмотів щось і поринув у глибокий сон. Коли старий накривав його ковдрою, по його вирослих м'язах відчув, що ця дитина вже досягла того віку, коли треба думати і про це, а тут ніяк не обійтися без гіркоти розчарувань. Ох, у цій справі ніхто нікого не замінить.

Старий знов обійняв саньсянь, погладив туго натягнуті струни, сам собі щосили бурмотів: ще одна обірвалася, ще одна обірвалася. Знову почав трясти інструмент, щоб почути тертя того легкого паперу об зміїну шкіру саньсяня. Тільки це може розсіяти його печалі і тривоги. Тут надія всього життя.

Юнакові приснився гарний сон. Він прокинувся та злякався, проспівав півень. Підвівся, щоб прислухатися, старий ще спав. Серце підказувало, що все спокійно. Намацав свою сумку, тихесенько дістав приймач і навшпиньки вийшов.

Пройшов трохи в бік долини Диких Овець, йому здалося, що тут щось не так. Крики птахів мало-помалу припинилися. У долині Диких Овець було тихо і зовсім не чутно людських голосів. Він остовпів на деякий час: тільки перший півнячий крик? Здогадався повернути ручку приймача, там теж було тихо. Зараз північ. Він уже слухав приймач уночі, там у цей час нічого немає. Для нього ця річ як годинник, тільки повернеш вмикач і відразу дізнаєшся, котра година, коли яка передача, все дуже точно.

Юнак повернувся в храм, старий лежав на другому боці.

- Що таке?

- По малій потребі ходив, - сказав юнак.

Весь ранок вчитель змушував його вправлятися в грі. I тільки після обіду юнак угледів добру нагоду вислизнути з храму, проникнути в село Диких Овець. Під деревами в тіні дрімали півні, під стінами дивилися свої сни свині, нещадно палило сонце, у селі було тихо. Стоячи на жорнах і тримаючись за стіну, юнак тихенько покликав:

- Лань Сюр... Лань Сюр...

У будинку пролунав громоподібний храп. Він трохи повагався та підвищив голос:

- Лань Сюр... Лань Сюр...

Загавкав собака. У кімнаті перестали хропіти і невдоволено запитали:

- Хто?

Юнак не посмів відповісти, голову сховав за стіну. У кімнаті прицмокнули губами і знову захропіли.

Він зітхнув, зістрибнув із жорен і ні з чим рушив назад, як раптом почув за спиною скрип воріт і слідом дрібні кроки наблизилися до нього. 
- Відгадай хто? - пролунав пронизливий голос, і пара м'яких долоньок охопили очі юнака. Але це вже занадто! Лань Сюр ще не виповнилося й п'ятнадцяти років, по правді кажучи, ще дитина.

- Лань Сюр!

- Приймач узяв чи ні?

Юнак підняв полу одягу - приймач висів на поясі.

- Тс-с, не тут, знайдемо місце, де нікого немає.

- Навіщо?

- Тоді притягнемо до себе людей.

- Ну і що?

- Будуть багато слухати, витратимо батарейки.

Дві людини пройшли туди, зайшли сюди і так дійшли до того невеликого джерела під горою. Юнак раптом про щось згадав і запитав:

- Ти бачила масляного вовка?

- Що?

- Масляного вовка.

- Масляного вовка?

- Знаєш?

- А ти знаєш?

- Звісно. А ще є зелена лава, тобто сидіння таке.

- Хто сидіння не знає?

- А що таке масляний вовк?

Лань Сюр похитала головою, захоплюючись юнаком. I тільки тепер з усією серйозністю юнак повернув ручку приймача. По гірській ущелині рознеслася весела пісенька. Тут було прохолодно і ніхто не заважав.

- Це пісня “Вище крок”, - підспівуючи і підстрибуючи, сказав юнак. Потім взявся підспівувати іншій пісні - "Грім у посуху”. Лань Сюр почувала себе присоромленою.

- Ця пісня називається "Чернець думає про дружину”.

Лан Сюр розсміялася:

- Брешеш!

- Не віриш?

$-\mathrm{Hi}$.

- Як хочеш. Тут розповідається багато дивного. - Юнак погрався з прохолодною водою, потім подумав і запитав: - Знаєш, що називають поцілунком?

- Що?

Тепер юнак розсміявся та нічого не відповів. Лань Сюр зрозуміла: напевно, щось нехороше, - почервоніла і більше не питала.

Закінчилася музика, і жіночий голос сказав: “А зараз будемо говорити про гігієну”.

- Що? - Лань Сюр не почула.

- Будуть розповідати про гігієну.

- Що це?

- Е-е-е, у тебе в голові є воші?

- Відчепись, не чіпай!

Юнак смикнув руки і поспішив пояснити:

- Якщо є, значить, негігієнічно.

- Тільки в мене немає.

Лань Сюр схопилася за голову, їй здалося, що трохи поколює.

- Ага, подивися на себе! - Лань Сюр одним махом притягнула голову юнака. Подивимося, скільки я зловлю.

У цей час стало чутно, як з іншого боку гори кликав старий:

- Синку, ще не повернувся! Пора вечерю готувати, поїмо і відразу за справу! Він стояв і прислухався. 
У долині Диких Овець було сутінно. Бекали вівці, кричали осли, гавкали собаки, шуміли діти. Від приготування їжі всюди стелився дим. У горах ще світило вечірнє сонце. Храм був у слабких променях, ні звуку.

Юнак знов роздував вогонь, стоячи на колінах. Старий сидів поруч і перебирав рис, він міг з рису на слух вибирати камінці.

- Сьогодні хмиз зовсім сухий, - сказав юнак.

- Еге.

- Краще тушити рис?

- Еге.

Юнак був піднесений, йому хотілося про щось говорити, але він знав, що гнів учителя ще не стих. Серце підказувало: треба трохи менше лаятися. Двоє людей мовчки робили кожен свою справу і також мовчки приготували їжу. У горах вже не було сонячних променів.

Юнак поклав рис у посудину і подав учителю:

- Їжте, - голос боязкий і надто слухняний.

Старий нарешті заговорив:

- Синку, послухай, що скажу, добре?

- Еге, - недбало відповів юнак, поспішно накладаючи рис у рот.

- Якщо не хочеш слухати, то не буду й говорити.

- Хто не хоче слухати? Я ж кажу - еге!

- Я бувала людина, все ж таки знаю більше за тебе.

Юнак з головою занурився в їжу.

- Я пройшов через це.

- Через що?

- Знову верзеш! - Старий відкинув палички.

- Лань Сюр лише хотіла послухати приймач. Ми разом тільки слухали приймач.

- Ще?

- Нічого.

- Нічого?

- Я ще запитав, чи бачила вона масляного вовка.

- Я не про це питаю.

- Потім, потім... - юнак уже не так хоробро тримався. - Не знаю, як раптом заговорили про воші...

- Ще?

- Все, справді все!

Двоє людей їли мовчки. Старий багато років водив за собою учня і знав, що він не вміє брехати. Можна бути спокійним, цей хлопчисько і чесний, і добрий.

- Послухай, що скажу, ручаюсь, тобі на користь. Тримайся подалі від неї.

- Лань Сюр - людина непогана.

- Я знаю, вона непогана. Але тобі краще бути подалі від неї. Колись зі мною так учитель говорив, а я не вірив...

- Учитель? Говорив про Лань Сюр?

- Яка Лань Сюр? Тоді не було їі, тоді не було вас.

Похмуре обличчя старого знову повернулося до густих сутінків небосхилу, неживі зіниці його очей безперервно оберталися. Невідомо, що він там “бачив”.

Через деякий час юнак вимовив:

- Сьогодні ввечері, дуже ймовірно, ви обірвете струну, - хотілося порадувати вчителя.

Цього вечора учень і вчитель грали в долині Диких Овець. "Минулого разу ми дійшли до смерті Ло Чена, душі Хунь і По ${ }^{11}$ вирушили в пекло. Слухайте пісню, мужі, не галасуйте. Панове, дозвольте продовжити розповідь. Душа Ло Чена вилетіла з підземного палацу, піднявся вихор, охопив порив вітру, недалеко від Чан’ань 
жив...” У старого звуки саньсяня були безладними, у юнака теж звуки саньсяня були безладними. Юнак згадував ті м'які долоні, що закрили йому очі і нахилили його голову. Старому ж було набагато більше про що думати...

Вночі старий спав неспокійно, весь час крутився. Постало безліч різних історій, які розгойдували його розум і серце, ніби щось хотіло вибухнути в тілі. “Ось і попався, захворюю", - подумав він. Паморочилось у голові, тіснило в грудях, все тіло ломило. Він присів і звернувся до себе: "Не можна хворіти, захворієш - тоді і не думай всі струни обірвати". Він знову намацав інструмент. Якщо слідом за ритмами серцевих рухів божевільно грати, страждання душі або згладить шум у вухах, або може навіть розсіяти його. А втім юнак спав дуже міцно.

Старому тільки залишалося знову із зусиллям думати про той рецепт і ті струни: ще залишилося кілька струн, залишилося всього кілька останніх струн. I тоді можна йти за ліками і можна буде побачити цей світ. Він багато разів переходив гори, багато разів ходив по дорогах, багато разів відчував теплоту і жар сонця, багато разів уявляв собі небо, і місяць, і зірки... Що іще? Що ж ще? Схоже, що в його туманних далях надією було щось набагато більше...

У горах гуляв нічний вітер.

Знову скорботно закричала сова.

Однак зараз він уже постарів. Не має значення, скільки йому ще залишилося жити. Втрачене вже назавжди втрачено. Ніби-то тільки зараз це зрозумів. Всі тяготи сімдесяти років потрібні були, щоб у кінці побачити світ. Чи варто? - питав він у себе.

Юнак уві сні усміхнувся і сказав:

- То стілець, Лань Сюр...

Старий тихо сидів, так само тихо сиділи й ті три, не розпізнати, чи то даоські, чи то буддійські, статуї.

Коли проспівав півень, старий вирішив разом із хлопчиком піти з долини Диких Овець. Інакше ні цього хлопчиська, ні навіть себе не витерпіти. Лань Сюр непогана, але чим це все може закінчитися, старий “бачив” краще за всіх.

Коли півні проспівали вдруге, старий почав збирати речі. Але вранці хлопець відчув нездужання, болів живіт, піднялася температура. Старому залишалося тільки відкласти день відходу.

Кілька днів поспіль старий розпалював вогонь або перебирав рис, збирав хмиз або викопував чи варив ліки, він весь час промовляв про себе: "Варто було, звичайно варто було". Якби він так невпинно не звертався до себе, всі фізичні сили, напевно, розвалилися би в прах: "Я не можу не побачити востаннє... Інакше як бути? Просто так померти? До того ж залишилося всього кілька останніх струн”. Останні три фрази звучали цілком резонно. Старий знову заспокоївся і щовечора ходив співати в долину Диких Овець.

Проте до юнака цього разу прийшла щаслива пора. Щовечора вчитель спускався 3 гір, а Лань Сюр, наче кішка, легко проникала в храм послухати приймач. Вона ще й варені яйця приносила - умовою було дозволити їй неодмінно самій крутити вмикач. “Куди крутити?” - “Праворуч”. - “Не крутиться”. - “Праворуч, дурепо. Не знаєш, де права рука?” Трохи поклацати, і вже неважливо, що прозвучить, і неважливо, хто ці двоє: все подобалося слухати.

Минуло ще кілька днів, старий обірвав ще три струни.

Цього вечора старий сам грав і співав: "Не буду казати про переродження Ло Чена, розповім про князя Лі Шиміня ${ }^{12}$. Князь проплакав усі очі, шкода улюбленого сановника, який загинув. Твоя смерть не важлива, не вистачає генералів, що підтримують династію...”

У храмі долини Диких Овець було жвавіше. На всю гучність звучав приймач, діти плакали, дорослі кричали, чутно було вибухи, стрілянину. До зали проникало

The World of the Orient, 2021, № 1 
місячне світло, юнак лежав та їв яйця, Лань Сюр сиділа поруч. Дві людини натхненно слухали скриньку, то голосно сміялися, то дивом замовкали.

- Твій учитель цей приймач де купив?

-3 рук чужинця.

- Ви ходили в далекі краї? - питала Лань Сюр.

- Ні. Коли-небудь я, звичайно, піду, поїду на паровозі.

- Паровоз?

- Ти і паровоз не знаєш, дурепо?

- А, знаю, знаю, з димом, що виривається, чи не так?

Через деякий час Лань Сюр знову сказала:

- Найімовірніше, мені доведеться поїхати далеко за гори, - голос трохи здригнувся.

- Ото так? - почувши це, юнак аж сів. - Так ти врешті-решт дізнайся, що таке масляний вовк.

- Скажи, це правда, що у всіх чужинців є приймач?

- Хто знає? Ти почула, що я кажу? Мас-ля-ний вовк, це якраз далеко за горами.

- Та мені від них потрібно один радіоприймач, - Лань Сюр думала про своє.

- Потрібно один? - юнак пару разів хмикнув, потім стримав роздратування, а потім розсміявся. - А чому не треба пару? Ти таки молодчина. Чи знаєш, скільки тисяч коштує один приймач? Продай тебе, боюся, і то не вистачить.

Відчувши образу, Лань Сюр одним рухом схопила його за вуха і з силою ущипнула, лаючись:

- Краще помри, сліпець!

У залі храму дві людини зчепилися в бійці. Три глиняні статуї стояли осторонь, не в змозі допомогти. Два молодих зростаючих тіла зіткнулися, переплелися, притулилися одне до одного і знову перекинулися. Лайка переросла в сміх. Поруч співав приймач.

Після тривалої боротьби вони від втоми відпустили руки, серця сильно стукотіли, лежали та переводили дух. Ні звуку. Ніхто не хотів посуватися, дихання Лань Сюр було спрямоване на обличчя юнака, він відчув спокусу. Згадавши слова вчителя, коли розпалювали вогонь, він подув в обличчя Лань Сюр, вона не відвернулася.

- Гей, - тихесенько сказав юнак, - знаєш, що таке поцілунок?

- Що? - голос Лань Сюр був теж тихий.

Юнак сказав їй на вухо. Вона нічого не відповіла. Перед поверненням старого вони спробували поцілуватися, це і справді виявилося зовсім не погано...

Саме в цей вечір старий порвав останні дві струни. Дві струни порвалися разом, дуже несподівано. Він чи не бігом видерся на гору Диких Овець і повернувся в храм.

Юнак злякався:

- Що трапилося, вчителю?

Задихаючись, старий сів, нічого не сказавши. Юнак навіть припустив: невже вчитель знає те, що сталося між ним і Лань Сюр?

Тільки тепер старий повірив у те, що все було варте. Страждання всього життя було варте. Мати можливість бачити, добряче бачити, все-все було варте.

- Малий, завтра я йду за ліками.

- Завтра?

- Завтра.

- Знову обірвали струну?

- Дві. Обидві обірвав.

Старий зняв ті дві струни, скрутив у руці, потім поклав їх до інших дев'ятисот дев'яноста восьми струн, скрутивши разом.

- Вже завтра вирушати?

- Розвидниться, і пора йти. 
У юнака завмерло серце. Старий почав здирати зміїну шкіру з корпусу інструмента.

- Але я ще не зовсім одужав, - тихо пробурмотів юнак.

- A-a, я подумав про це. Ти, мабуть, сиди тут, не мине й десяти днів, як я повернусь.

Юнак несподівано для себе зрадів.

- Чи можна тобі залишатися одному?

- Можна! - поспішно відповів юнак.

Старий давно забув про Лань Сюр.

- Пити, їсти, розпалювати вогонь - усе є. Якщо одужаєш, спробуй самостійно грати. Гаразд?

- Гаразд. - Юнакові здалося, що він недостойний учителя.

Старий зняв шкіру з корпусу інструмента, дістав акуратно складений аркуш паперу. Він згадав, що, коли цей рецепт поклали в інструмент, йому було лише двадцять років. Все тіло ніби похололо. Юнак теж із деякою шанобливістю помацав той рецепт.

- Життя з моїм учителем обійшлося дуже несправедливо.

- Скільки він обірвав струн?

- Спочатку він міг обірвати тисячу струн, але зазначив лише вісімсот. Інакше він зміг би обірвати й тисячу струн.

Ще не розвиднилося, а старий уже пішов. Він сказав, що повернеться щонайбільше днів через десять. Ніхто не міг припустити, що він піде так надовго.

Уже була зима, коли старий повернувся в долину Диких Овець. Цілими днями йшов сніг, сіре небо зливалося з білими горами. Ні звуків, ні голосів, ні життєвої сили навколо, тільки неосяжна далечінь і глибока тиша. Тому той почорнілий солом'яний капелюх старого особливо вирізнявся на цьому тлі. Він шкутильгаючи дерся на гору Диких Овець. У храмі шелестіла засохла трава, з-під ніг кинулася навтьоки лисиця і в паніці втекла.

У селі йому сказали, що вже кілька днів, як юнак пішов.

- Я сказав йому, щоб чекав мене.

- Невідомо чому він раптом пішов.

- Він не сказав куди? Нічого не передав мені?

- Він сказав, щоб ви не шукали його.

- Коли пішов?

Після довгих роздумів всі зійшлися на тому, що в той день, коли Лань Сюр видали заміж за чужинця. Старий усе зрозумів.

Жителі вмовляли старого залишитися. Куди йти під холодним небом і по засніженій землі? Краще співати всю зиму в долині Диких Овець. Старий показав на саньсянь, і всі побачили, що гриф у саньсяня порожній, зовсім без струн. Побачили, що в старого дихання слабке, обличчя виснажене і голос хрипкий, - зовсім інша людина. Він сказав, що піде шукати учня.

Якби не думки про юнака, старий не повернувся б у долину Диких Овець. Той рецепт, який зберігався п'ятдесят років, виявився порожнім білим папером. Він не повірив, просив тих, хто знає ієрогліфи і просто чесних людей подивитись, але всі казали йому, що й справді, це всього лише порожній аркуш білого паперу.

Старий трохи посидів на ганку аптечної крамниці, думав, що трохи, а виявилося, кілька днів і ночей. Закостенілі зіниці запитливо звернулися до неба. Обличчя його стало блідо-сірого кольору кісток. Хтось подумав, що він збожеволів, хтось втішав його, заспокоював. Старий гірко усміхався: у сімдесят років збожеволіти, що тут такого? Він усього лише не буде більше грати. Все, що притягувало його до життя, до ходьби, до співу, раптом зовсім зникло, все одно що струна, яку не можна натягнути, а тим паче на якій не можна зіграти мелодійну музику, що тішить серце. Струни серця старого обірвалися. Тільки зараз він помітив, що та мета виявилася порожньою.

The World of the Orient, 2021, № 1 
Старий довго жив на заїжджому дворі, відчуваючи, що все в тілі згасає. Цілими днями не підводився з ліжка, не грав, не співав, 3 кожним днем дедалі більше і більше слабшав. До того, як розтратив усі гроші, до того, як раптом згадав про свого учня, він знав, що його смертний час наближається. Однак той хлопчисько чекає на його повернення.

Серед безкрайніх білосніжних гір десь між небом і землею проступала чорна крапка. Зблизька здається, що тінь старого вигнута, наче старий міст. Він ішов шукати учня, знав, що зараз відчуває цей хлопчина. Він думав про те, що необхідно спочатку самому підбадьоритися, але не виходить, попереду тільки безсумнівно одне - мети немає.

Він ішов і з любов'ю згадував минулі дні, і тоді він зрозумів, що метушливі, але й живодайні гори, дороги, гра на саньсяні і навіть хвилювання та печалі - все це було таке радісне! Тоді було щось, що міцно натягало струни його душі, незважаючи на те що від самого початку це була лише фікція. Старий згадав, як помирав його вчитель. Той рецепт, що самому не знадобився, вчитель запечатав у його інструмент.

- Не вмирайте, поживіть ще кілька років і тоді ви розплющите очі й побачите світ, - він був ще хлопчиком, коли казав це.

Його вчитель довго нічого не говорив, потім сказав:

- Запам'ятай, життя людини як ця струна: натягнеш - тоді зможеш зіграти, зіграв - та й годі.

...Оце так, виявляється, сенс у тому, що мети як такої немає. Старий зрозумів, як йому розмовляти зі своїм учнем. І знову подумав: чи потрібно хлопчику все казати? Він спробував підбадьорити себе, але не виходило. Неможливо звільнитися від цього білого паперу...

Старий знайшов юнака глибоко в горах.

Він лежав у снігу в очікуванні смерті без жодного руху. Старий розумів, що ця туга точно не удавана. Він втягнув знесиленого юнака в печеру.

Старий зібрав трохи хмизу, розпалив вогонь. У юнака потроху почало прориватися схлипування. Тоді старий заспокоївся. Нехай досхочу наплачеться. Якщо може плакати, можливе й полегшення, якщо може плакати, то прийде час, коли висохнуть сльози.

Дні і ночі плакав юнак, старий не казав ні слова, чекав. Вогонь і ридання налякали диких овець, зайця, фазана, лисиць і яструбів...

Нарешті юнак заговорив:

- Чому ми сліпі!

- Тому що сліпі, - відповів старий.

Нарешті юнак знову сказав:

- Я хочу розплющити очі, щоб бачити, вчителю, я хочу розплющити очі, щоб бачити! Нехай навіть один раз.

- Ти і справді так думаєш?

- Так.

Старий ще більше розпалив багаття.

Сніг припинився. У свинцевому небі, немов осяйне дзеркальце, показалося сонце. Спокійно літали яструби. грай.

- Тоді грай на саньсяні, - сказав старий, - на кожній струні всіма силами душі

- Вчителю, ви дістали ліки? - юнак немов прокинувся.

- Запам'ятай, потрібно грати по-справжньому, тоді вийде.

- Ви вже бачите? Вчителю, ви зараз можете бачити?

Юнак підвівся з останніх сил, простягнув руки, щоб доторкнутися до очей учителя. Старий схопив його руки.

- Запам'ятай, потрібно обірвати тисячу двісті струн.

- Тисячу двісті? 
- Дай мені твій саньсянь, я цей рецепт покладу в нього. - Тільки зараз старий зрозумів, що тоді казав йому вчитель, - наше життя в цьому саньсяні.

Мета хоча і порожня, але іiї не можна не мати. Інакше як тоді натягнути струни. Не натягнеш - не зіграєш.

- Чому тисячу двісті, вчителю?

- Саме тисячу двісті, я не дограв, я зазначив лише тисячу.

Старий подумав про те, що нехай цей хлопчисько так і грає. Чи зможе обірвати тисячу двісті струн? Вічно натягувати дзвінкі струни і зовсім не варто йти дивитися на той порожній білий аркуш паперу...

У нескінченному пасмі гір це було глухе і безлюдне місце. У непрохідних заростях час від часу злітав фазан або вистрибували дикий заєць, лисиця чи інші звірятка. У гірських ущелинах ширяли яструби.

Тепер повернімося до початку...

У сизих заростях гірських схилів йшли двоє сліпців, один - старий, другий - молодий, один - попереду, другий - позаду. Два почорнілих солом'яних капелюхи поспішно просувалися вперед, немов неспокійний річковий потік. Неважливо, звідки йшли і куди йшли, і неважливо, хто був хто...

20 квітня 1985 року

\footnotetext{
${ }^{1}$ Саньсянь (三弦 sānxián) - традиційний китайський триструнний щипковий музичний інструмент, що використовується як акомпанемент у китайській опері, традиційному цзяннанському ансамблі сичжу (江南丝竹), а також при виконанні оповідних пісень.

${ }^{2}$ Шошуди (说书的 shuōshüde) - вуличні оповідачі, які з допомогою музичного інструмента розповідають билиці, легенди, різні історії, як правило, у багатолюдних місцях, на ринках тощо.

${ }^{3}$ Пань-гу (盘古 Pángǔ) - персонаж давньокитайської міфології, перша людина, яка розділила світ на Небо і Землю.

${ }^{4}$ Три володарі і п’ять імператорів (三皇五帝 sān huáng wǔ dì) - легендарні правителі найдавнішого періоду історії Китаю, що належить до третього тисячоліття до нашої ери.

5 Дун Юн (董永 Dǒng Yǒng) - персонаж народної легенди династії Хань, історичний зразок синовньої шанобливості.

${ }^{6}$ У Ерлан (武二郎 Wǔ Erláng) - інше ім’я відомого персонажа У Суна (武松 Wǔ Sōng) 3 китайського роману XIV століття “Річкові заплави” (水吘传).

${ }^{7}$ Цінь Сянлянь (秦香莲 Qín Xiānglián) - вигаданий персонаж у традиційній китайській музичній драмі “Чжамей’ань” (“钢美案”). Ця історія вельми поширена й була адаптована до опери. Цінь Сянлянь символізує покинутих жінок.

8 Ло Чен (罗成 Luō Chéng) - персонаж творів династій Суй і Тан, володіє стрілецькою майстерністю, через світлу шкіру та красиве обличчя, яке ніколи не усміхається, люди дали йому прізвисько "Вродливий Ло Чен з холодним обличчям та холодною зброєю".

${ }^{9}$ Мен Цзян-нюй (孟姜女 Mèng Jiāng-nü) - легенда стародавнього Китаю 3 багатьма варіаціями, одна 3 чотирьох відомих легенд про кохання. Пізніші версії встановлюються в період династії Цінь. Легенда про жінку, чиї сльози розмили ділянку Великої стіни, де був замурований ії чоловік.

${ }^{10}$ Су Ле (苏烈 Sū Liè) - інше ім'я Су Дінфана (苏定方 Sū Dìngfāng), відомого полководця, який розширив територію ранньої династії Тан. Імператор Тан Гаоцзун глибоко цінував його і дуже довіряв йому. За його видатні досягнення і чесність йому багато разів доручали важливі завдання.

${ }^{11}$ Душі Хунь і По (三魂七魄 sānhún qīpò) - дослівно: три душі Хунь і сім душ По. У китайському даосизмі вважається, що людська душа ділиться на три розумні душі Хунь (після смерті людей повертаються на Небо) і сім тваринних душ По (після смерті повертаються на Землю).

12 Лі Шимінь (李世民 Lǐ Shìmín) - другий імператор династії Тан (Тан Тай-цзун), Лі Шимінь - ім'я при народженні. Наймогутніший китайський імператор династії Тан.
} 


\section{ЛІТЕРАТУРА}

Бломберг К. Интерпретация притчей. Москва, 2005.

Камю А. Міф про Сізіфа. Есе / Український переклад - О. Жупанський. Харків, 2015.

Токарчук $O$. Що говорила Токарчук на врученні Нобеля: від ніжного оповідача до політики // Читомо. Портал про культуру читання і мистецтво книговидання. 10.12.2019. URL: https://chytomo.com/shcho-hovoryla-tokarchuk-na-vruchenni-nobelia-vid-nizhnoho-opovidacha-do-polityky/ (дата звернення: 27.02.2021).

史铁生 一 职业是生病 业余在写作。2016-05-13. URL: http://www.wakbook.com/Article/ 1x0000000002/139440x11213/STANZA_52.html (дата звернення: 27.02.2021).

史铁生 - 人生不是为了写作, 写作是为了人生! URL: https://kknews.cc/zh-sg/news/ p4e9pe.html (дата звернення: 27.02.2021).

\section{REFERENCES}

Blomberg K. (2005), Interpretatsiya pritchey. Bybleysko-bohoslovskyy ynstytut sv. apostola Andreya, Moscow. (In Russian).

Kamyu A. (2015), Mif pro Sizifa, Ese, Transl. into Ukrainian by O. Zhupans'kyy, Portfel', Kharkiv. (In Ukrainian).

Tokarchuk O. (2019), "Shcho hovoryla Tokarchuk na vruchenni Nobelya: vid nizhnoho opovidacha do polityky", in Chytomo. Portal pro kul turu chytannya i mystetstvo knyhovydannya, December 10, available at: https://chytomo.com/shcho-hovoryla-tokarchuk-na-vruchenni-nobeliavid-nizhnoho-opovidacha-do-polityky/ (accessed February 27, 2021). (In Ukrainian).

Shǐtiěshēng, Zhíyè shì shēngbìng yèyú zài xiězuò, available at: www.wakbook.com/Article/1x 0000000002/139440x11213/STANZA_52.html (accessed February 27, 2021). (In Chinese).

Shǐtiěshēng (2016), Rénshēng bùshì wèile xiězuò, xiězuò shì wèile rénshēng!, available at: https://Kknews.Cc/zh-sg/news/p4e9pe (accessed February 27, 2021). (In Chinese).

\section{Ши Тешен \\ ЖИТТЯ ЯК НАТЯГНУТА СТРУНА /}

Переклад з китайської, вступна стаття та коментарі Н. О. Черниш

До уваги читача пропонується знайомство з творчістю китайського письменника Ши Тєшена, відомого автора романів, оповідань та есе XX століття. Багато його творів входять у підручники китайських шкіл. Академічний інтерес до творчості Ши Тєшена 3 кожним роком зростає, зокрема багато досліджень присвячені його оповіданню “Життя як натягнута струна” (“命若琴弦”). Оповідання “Життя як натягнута струна” має всі ознаки притчі. Це й повчально-алегоричний сюжет, побудований на прихованому порівнянні; це й символічність, образність, яскрава алегоричність. Оповіданню властивий принцип параболи: оповідь немовби відривається від зазначеного часопростору i, рухаючись по кривій, повертається назад, дає філософсько-етичне осмислення предмета, у “надчасовому” міститься характеристика сучасності, конкретна дія повідомляє про вічне.

На думку авторки перекладу, краще зрозуміти розповідь-притчу Ши Тєшена допомагає саме філософія А. Камю. Можна припустити, що сам Ши Тєшен був знайомий з філософією А. Камю, твори якого вже з 1958 року почали публікуватися китайською мовою. Ши Тєшен в образі головного героя своєї притчі ставить ті ж питання, що й Камю в знаменитому есе про абсурд "Міф про Сізіфа": що спонукає людину до дії, що таке почуття абсурду, почуття надії та безнадії, що таке жага ясності (абсолюту), примирення з долею, творчість тощо. Розмірковуючи про абсурдність людського життя, Ши Тєшен шукає надійну основу для нього. В оповіданні “Життя як натягнута струна" в протистоянні долі перемагає не стоїчне прийняття своєї долі, що підкріплюється розумінням її абсурду і свободи своїх дій, а розчинення себе в іншому, бачення іншого, перекидання своєї уваги на іншого, і ця здатність розуму, чи стан духу, чи природа характеру, називається в китайській традиції “людяність”, “людинолюбність”, “гуманність” і навіть “совість”. Ці слова об’єднує ієрогліф жень 仁 (ren).

Переклад українською мовою оповідання “Життя як натягнута струна” здійснюється вперше.

Ключові слова: Ши Тєшен, “Життя як натягнута струна”, оповідання, притча, алегорія, метафора, принцип параболи, абсурд, А. Камю, “Міф про Сізіфа”

Переклад надійшов до редакиії 26.01.2021 